\title{
Effect of Family Support and Peer Support on The Quality of Life of The Elderly: A Path Analysis Evidence from Jember, East Java
}

\author{
Malinda Capri Nurul Satya), RB. Soemanto'), Bhisma Murti') \\ ${ }^{1)}$ Masters Program in Public Health, Universitas Sebelas Maret \\ 2)Faculty of Social and Political Science, Universitas Sebelas Maret
}

\begin{abstract}
Background: Indonesia is one of the countries with an elderly population by $>7 \%$. It may increase every year. The number of elderly people will increase globally and lead to several problems such as health, psychological, social, and economic problems. Other psychological problems experienced by the elderly are loneliness due to loss of spouse, separation from family, and loss of peers. This study aimed to analyze the effect of family support and peer support on the quality of life of the elderly.

Subjects and Method: This was a cross-sectional study carried out at of Tresna Werdha social service, in Wuluhan, Jember, East Java, from August to September 2019. A sample of 200 elderly aged $>60$ years old was selected by fixed exposure sampling. The dependent variable was quality of life. The independent variables were education, healthy behavior, family income, family support, peer support, and residence. The study was collected by questionnaire and analyzed by path analysis.
\end{abstract}

Results: Good quality of life on the elderly increased with healthy behavior $(b=1.06$; 95\% CI 0.25 to $1.87 ; \mathrm{p}=0.010$ ), education $\geq$ Senior high school ( $\mathrm{b}=1.33$; 95\% CI 0.37 to $2.29 ; \mathrm{p}=0.007$ ), family income $\geq \operatorname{Rp} 2,170,000(b=1.59 ; 95 \%$ CI 0.17 to $3.02 ; p=0.028)$, strong family support $(b=1.93$; 95\%CI 0.47 to $3.39 ; \mathrm{p}=0.010)$, strong peer support $(\mathrm{b}=1.18 ; 95 \% \mathrm{CI}=0.21$ to $2.16 ; \mathrm{p}=0.017)$, and residence at home $(b=1.46 ; 95 \% \mathrm{CI} 0.26$ to $2.65 ; \mathrm{p}=0.017)$.

Conclussion: Good quality of life on the elderly increased with healthy behavior, education $\geq$ Senior high school, high family income, strong family support, strong peer support, and residence at home.

Keywords: quality of life, family support, peer support

\section{Correspondence:}

Malinda Capri Nurul Satya. Masters Program in Public Health, Universitas Sebelas Maret. Jl. Ir. Sutami 36A, Surakarta, Central Java, Indonesia. Email: malindacaprins@gmail.com. Mobile: 085236936546

\section{BACKGROUND}

The number of elderly people increases every year. It occurs due to low fertility rates and an increase in life expectancy (UHH). Indonesia has a population projection with a higher life expectancy compared to some countries in Asia (Central Bureau of Statistics, 2018). This condition is a challenge for the elderly, family, community, and government. The most important challenge is how to maintain the quality of life of the elderly well (Ministry of Health, 2016).
Data from The World Bank in 2018 showed that the elderly population in the world aged over 65 years was 673,618,927 million; it may increase every year. The elderly population in Indonesia in 2018 was 24.49 million or $9.27 \%$. The most dominant elderly group was the young elderly group (aged 60-69 years) with a percentage by $63.39 \%$ (Central Bureau of Statistics, 2018).

The number of elderly people will increase globally and lead to several problems such as health, psychological, social, and economic problems (Ministry of 
Journal of Health Promotion and Behavior (2019), 4(3): 159-169

https://doi.org/10.26911/thejhpb.2019.04.03.01

Health, 2014). Other psychological problems experienced by the elderly are loneliness due to loss of a spouse, separation from family, and loss of peers. The majority of the elderly population in Indonesia still lives together with their families. However, many of elderly people also live in social institutions or nursing homes. Living environment is one of the important factors that affects the quality of life of the elderly.

Good family and peer support plays an important role in improving the quality of life of the elderly. Strong family and peer support directly affects psychological aspects such as loneliness and can reduce the risk of depression (Suwarni et al., 2018).

\section{SUBJECTS AND METHOD}

\section{Design of the Study}

This was an analytic observational study with a cross sectional design. The study was conducted at Tresna Werdha social service and the elderly integrated health post, in Wuluhan, Jember, East Java, from AugustSeptember 2019.

\section{Population and Sample}

A sample of 200 elderly aged $>60$ years old was selected by fixed exposure sampling.

\section{Study Variables}

The dependent variable was the quality of life of the elderly. The independent variables were family support, peer support, healthy behavior, residence, education, and family income.

\section{Operational Definition}

Family support was defined as a support given by members who had marriage ties or blood relations in the form of emotional support, information support, instrumental support, and appreciation support. The data were collected by questionnaire. The measurement scale was.

Peer support was support given by friend who had the same age, experience, and interest in the form of emotional support, information support, instrumental support, and appreciation support. The data were collected by questionnaire. The measurement scale was continous, but it was transformed into dichotomous.

Healthy Behavior was an elderly activity related to maintaining and improving health which included balanced nutrition, efforts to prevent and protect themselves from disease, efforts to seek treatment when they were sick, and stress control. The data were collected by questionnaire. The measurement scale was continous, but it was transformed into dichotomous.

Residence was a place where the elderly lived for their survival. In addition, there was a socialization process inside. The data were collected by questionnaire. The measurement scale was continous, but it was transformed into dichotomous, coded o fo living in tresna werdha social service and 1 for living at home.

Education was measured by looking at the last formal education of the elderly. The data were collected by questionnaire. The measurement scale was categorical, coded o for $<$ Senior high school and 1 for $\geq$ Senior high school.

Family Income was measured by the income earned each month based on the minimum wage that was used to meet shared and individual needs. The data were collected by questionnaire. The measurement scale was continous, but it was transformed into dichotomous.

Quality of Life was the perception of the elderly about their situation or position in their lives. The data were measured by WHOQOL-BREF questionnaire. The measurement scale was continous, but it was transformed into dichotomous.

\section{Study Ethics}

Research ethics consisted of informed consent form, anonymity, confidentiality, 
and ethical clearance. Ethical clearance in this study came from the Research Ethics Committee in Dr. Moewardi Hospital, Surakarta Number: 971/VIII/HREC/2019.

\section{RESULTS \\ 1. Sample characteristics}

Sample characteristics of continous data were showed in the Table 1. Sample characteristics of categorical data were showed in the Table 2.

Table 1. The description of the charact

\begin{tabular}{lccccc}
\hline \multicolumn{1}{c}{ Variable } & n & Mean & SD & Min. & Max. \\
\hline Quality of life & 200 & 75.32 & $5 \cdot 72$ & 55 & 88 \\
Family support & 200 & 74.02 & 9.59 & 35 & 89 \\
Peer support & 200 & 55.23 & $5 \cdot 52$ & 40 & 67 \\
Healthy behavior & 200 & 51.75 & 4.93 & 39 & 62 \\
Family income (Rupiah) & 200 & $1,204,225$ & 869,079 & 20,000 & 4,000, ooo \\
\hline
\end{tabular}

Table 2. The description of the characteristic of the sample of the categorical data

\begin{tabular}{lcc}
\hline \multicolumn{1}{c}{ Variable } & Frequency & \% \\
\hline Quality of Life & 87 & 44.0 \\
Poor & 113 & 56.0 \\
Good & & \\
Education & 142 & 71.0 \\
Low (<Senior high school) & 58 & 29.0 \\
High ( $\geq$ Senior high school) & & \\
Employment Status & 78 & 39.0 \\
Unemployed & 122 & 61.0 \\
Employed & & \\
Marital Status & 75 & 37.5 \\
Unmarried/widow/widower & 125 & 62.5 \\
Married & & \\
Family Income & 163 & 18.5 \\
Low (<Rp 2,170,ooo) & 37 & 14.0 \\
High ( $\geq$ Rp 2,170,o00) & & 61.0 \\
Residence & 28 & 25.0 \\
Living alone & 122 & 30.5 \\
With family & 50 & 69.5 \\
Nursing home & & \\
Family Support & 61 & 28.5 \\
Weak & 139 & 71.5 \\
Strong & & 24.0 \\
Peer Support & 57 & 76.0 \\
Weak & 143 & \\
Strong & & \\
Healthy Behavior & 48 & \\
Poor & 152 & \\
Good & & \\
\hline
\end{tabular}


There were 163 study subjects (81.5\%) who had low family income $(<\mathrm{Rp} 2,170,000)$ and 37 study subjects (18.5\%) who had high income ( $>\operatorname{Rp~2,170,000).~The~elderly~who~}$ lived alone were 28 study subjects (14.0\%), lived with families as many as 122 study subjects (61.0\%), and lived in nursing home as many as 50 study subjects (25.0\%). There were 61 study subjects (30.5\%) who had weak family support and 139 study subjects (69.5\%) who had strong family support.

There were 57 study subjects (28.5\%) subjects (71.5\%) who had strong peer support. There were 48 study subjects (24.0\%) who had poor healthy behavior and 152 study subjects who had good healthy behavior (76.0\%)

\section{Bivariate Analysis}

This bivariate analysis used Chi Square analysis. Table 3 shows family support $(\mathrm{OR}=14.59$; $\mathrm{p}<0.001)$, peer support $(\mathrm{OR}=$ 2.27; $\mathrm{p}<0.010)$, healthy behavior $(\mathrm{OR}=1.13$; $\mathrm{p}<0.001)$, residence $(\mathrm{OR}=23.14 ; \mathrm{p}<0.001)$, education $(\mathrm{OR}=9.40 ; \mathrm{p}<0.001)$, and family income $(\mathrm{OR}=12.05 ; \mathrm{p}<0.001)$.

who had weak peer support and 143 study

Table 3. The Chi Square test of factors affecting the quality of life of the elderly

\begin{tabular}{|c|c|c|c|c|c|c|}
\hline \multirow[t]{2}{*}{ Variable of the Study } & \multicolumn{2}{|c|}{$\begin{array}{c}\text { Poor Quality of } \\
\text { Life }\end{array}$} & \multicolumn{2}{|c|}{$\begin{array}{c}\text { Good Quality of } \\
\text { Life }\end{array}$} & \multirow[t]{2}{*}{$\mathbf{O R}$} & \multirow{2}{*}{$\mathbf{p}$} \\
\hline & $\mathbf{n}=\mathbf{8 7}$ & $\%$ & $\mathbf{n}=\mathbf{1 1 3}$ & $\%$ & & \\
\hline \multicolumn{7}{|l|}{ Family Support } \\
\hline Weak & 51 & 58.6 & 10 & 8.8 & 14.59 & $<0.001$ \\
\hline Strong & 36 & 41.4 & 103 & 91.2 & & \\
\hline \multicolumn{7}{|l|}{ Peer Support } \\
\hline Weak & 33 & 37.9 & 24 & 21.2 & 2.27 & 0.010 \\
\hline Strong & 54 & 62.1 & 89 & 78.8 & & \\
\hline \multicolumn{7}{|l|}{ Healthy Behavior } \\
\hline Poor & 22 & $25 \cdot 3$ & 26 & 23 & 1.13 & $<0.001$ \\
\hline Good & 65 & 74.7 & 87 & 77 & & \\
\hline \multicolumn{7}{|l|}{ Residence } \\
\hline Nursing home & 45 & 51.7 & 5 & 4.4 & 23.14 & $<0.001$ \\
\hline Home & 42 & 48.3 & 108 & 95.6 & & \\
\hline \multicolumn{7}{|l|}{ Education } \\
\hline Low (<Senior high school) & 80 & 92 & 62 & 54.9 & 9.40 & $<0.001$ \\
\hline High ( $\geq$ Senior high school) & 7 & 8 & 51 & 45.1 & & \\
\hline \multicolumn{7}{|l|}{ Family Income } \\
\hline$<\operatorname{Rp} 2,170,000$ & 84 & 96.6 & 79 & 69.9 & 12.05 & $<0.001$ \\
\hline$\geq \operatorname{Rp} 2,170,000$ & 3 & 3.4 & 34 & 30.1 & & \\
\hline
\end{tabular}

\section{Path Analysis}

This multivariate analysis used path analysis method with Stata 13. Table 4 shows that there were effects of family support, peer support, healthy behavior, education, and family income on the quality of life of the elderly. The result showed that strong family support $(b=1.93 ; 95 \% \mathrm{CI}=0.47$ to 3.39; $\mathrm{p}=0.010)$, strong peer support $(b=$
1.18; 95\% $\mathrm{CI}=0.21$ to $2.16 ; \mathrm{p}=0.017)$, good healthy behavior $(b=1.06 ; 95 \% \mathrm{CI}=0.25$ to 1.87; $\mathrm{p}=0.010)$, living at home $(\mathrm{b}=1.46$; 95\% CI $=0.26$ to $2.65 ; \mathrm{p}=0.017)$, higher education ( $\geq$ Senior high school) $(b=1.33$; 95\% CI= 0.37 to $2.29 ; \mathrm{p}=0.007$ ), and high family income ( $\geq$ Rp. 2,170,000) $(b=1.59$; $95 \% \mathrm{CI}=0.17$ to $3.02 ; \mathrm{p}=0.028$ ) improved the quality of life of the elderly. 
Table 4. The path analysis of the effect of family support and peer support on the quality of life of the elderly

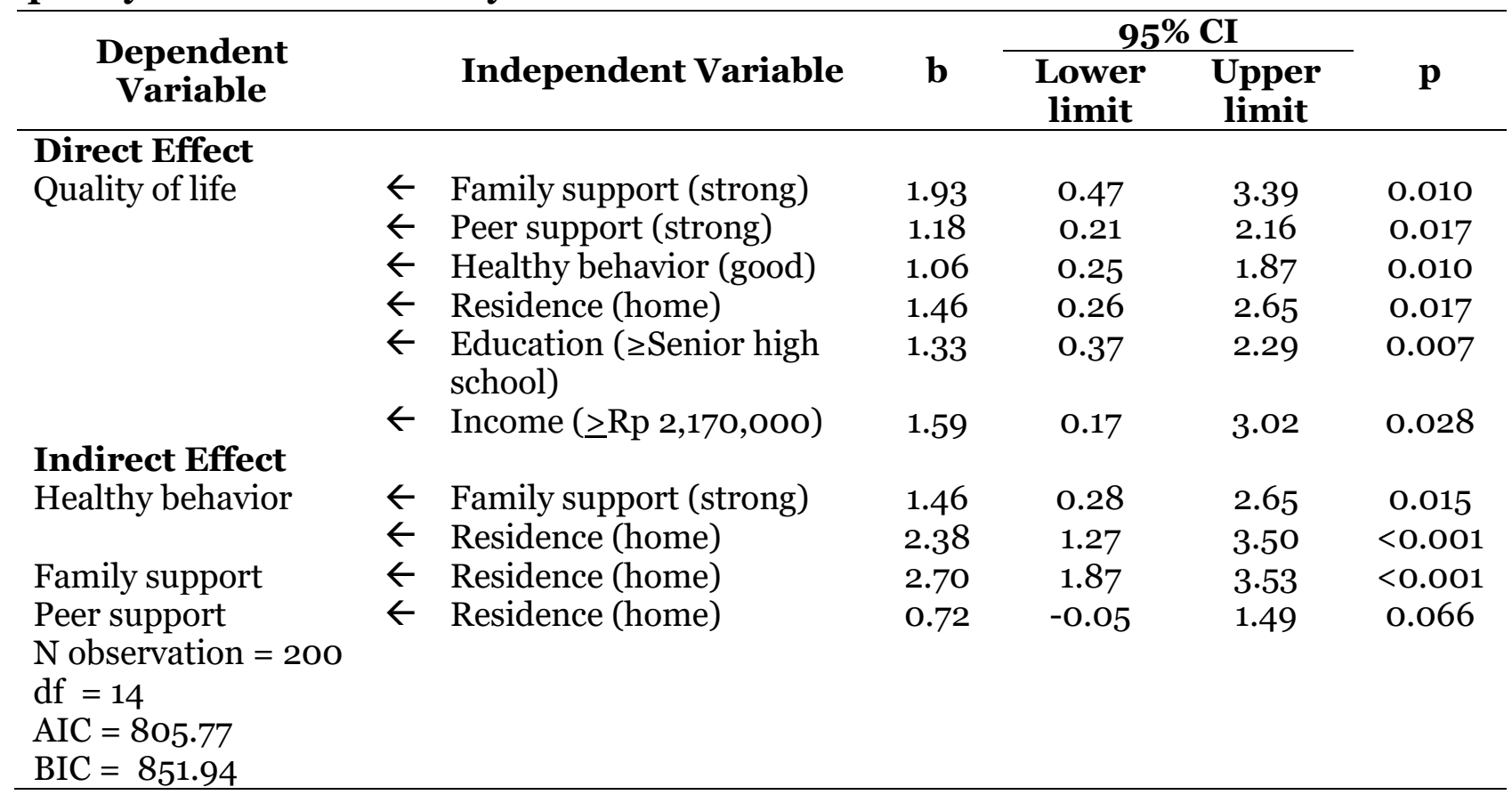

\section{DISCUSSION}

1. The effect of family support on the quality of life of the elderly

Family is the main background in which most people are born, grow, become mature, and old. The main socialization of most people is carried out in the family. For many people, family affects the resolution of the problems they face and make a significant contribution to their lives (Uddin and Bhuiyan, 2019). Family plays an important role in determining the biopsychosocial condition of the elderly that can increase the quality of life of the elderly (Yuliati et al., 2014).

The study result of path analysis indicated that there was a direct effect of strong family support on the improvement of the quality of life of the elderly. Family is a place to meet physical and emotional needs for each individual. The process of adaptation, growth, development (maturing every member of the family), affection, and togetherness will occur in the family. If the family function goes well, living together with the family members will create comfort. Family becomes a shelter and supporter of all aspects both physically and mentally for the elderly (Sherizadeh et al., 2016). The majority of the study subjects who lived in communities or homes had stronger family support than they who lived in nursing homes.

\section{The effect of peer support on the quality of life of the elderly}

The sense of giving and interrelation that occur between peers makes the life of the elderly more valuable. This support makes the elderly more enthusiastic in doing their activities; therefore, it improves the wellbeing of the elderly. Peer support or social support increases the well-being of parents. Perceived social support is associated with the interrelation with peers (Larocca and Scogin, 2016; Casey et al., 2016).

There was a direct effect between peer support and the quality of life of the elderly. Creating social relationship and increasing social networking among peers brings the elderly to have a good quality of life. Half of 
the elderly are in the isolation. They are at high risk of withdrawing from social life. The quality of social networking can be carried out if peers and the surrounding community are more receptive to the condition of the elderly and encourage the elderly to voluntarily participate in various activities; thus building self-confidence in the elderly (Bahramnezhad et al., 2017). Strong peer support can reduce feelings of loneliness in the elderly; in addition, the low loneliness can improve the quality of life of the elderly (Azwan et al., 2015).

\section{The effect of healthy behavior on the quality of life of the elderly}

The result of the study showed that healthy behavior directly affected the quality of life of the elderly. The components of healthy behavior such as physical activity, balanced nutrition, stress control, and social relation affect the quality of life of the elderly. A healthy lifestyle affects the quality of life of the elderly. Physical activity and food pattern are the most related variables in affecting the quality of life of the elderly. However, it is important to emphasize that those factors are not always independent predictors of good quality of life. The relationship of psychosocial aspects (family support, peer support, stress management, and participation in religious activities) contribute in affecting the quality of life of the elderly (Ferreira et al., 2018).

Healthy life behavior is behavior that is related to the efforts or activities of a person to maintain and improve their health. One of the efforts to improve health is by carrying out routine physical activity. This activity can make the elderly feel happy. Physical activity has a strong effect on the domain of healthy behavior and the quality of life of the elderly. Immobility is an important component that can disrupt their happiness. Routine physical activity makes their life happier in their daily activities (Pernambuco et al., 2012).

\section{The effect of residence on the qua- lity of life of the elderly}

The result of the study showed that residence directly affected the quality of life of the elderly. Elderly who lived with family in the community or at home would increase family support. Increased family support had a positive effect on the quality of life of the elderly.

The important factor that affects the quality of life of the elderly on the variable of residence is the environment around the residence. Changes in the residential environment will change the role of the elderly in adapting. Different residential environment will change the physical, social, economic, psychological, and spiritual conditions, thus affecting the health status and quality of life of the elderly (Wulandari, 2011).

One of the most important foundations for seeing the ability of the elderly to improve the quality of life is to be able to enjoy various facilities to access various services around their residences, such as trade services, public services, and health services (Granbom et al., 2016). Elderly people who live at home can easily go to several service places. However, elderly people who live in nursing home have a little bit opportunity to go anywhere (Panday et al., 2015).

\section{The effect of education on the qua- lity of life of the elderly}

Education is one of the factors that affect the quality of life of the elderly. The higher level of education makes the elderly able to understand and handle any problems that disrupt their quality of life in a wise way. A person's ability to manage information and determine how easy it is to receive every update can be affected by education (Andesty and Syahrul, 2018). 
Elderly who had high education had a logodd of higher quality of life 0.82 than elderly who had low education (Prasetyaningsih et al., 2016). In addition, a study conducted in Poland showed that good education had an effect by 2.31 times in improving the quality of life of the elderly (Bryla et al., 2013).

\section{The effect of income on the quality of life of the elderly}

The amount of income will describe the family economy in a society. Meeting the needs of families that will improve the quality of life of the elderly will occur if the income increases (Kosim et al., 2015).

High family income had an effect by 1.63 times in improving the quality of life of the elderly to be better than the elderly with low income (Bryla et al., 2013). Based on a study conducted by Farziapour et al (2012), education and income are the most important factors affecting quality of life. In addition, income plays an important role in improving the quality of life of the elderly in Ireland (Layte et al., 2013). All domains in quality of life can be affected by income except sensory abilities (Bilgili and Arpaci, 2014).

\section{The effect of family support on the healthy behavior of the elderly}

The interaction with family and kinship networks has a big effect on the health behavior of the elderly. Elderly who are respected play a role model in their families and communities by providing good examples and support in health behavior (Waterworth et al. 2015).

Huidobro and Mendenhall (2015) states that family is a place to learn healthy behavior. Family is the main support system for the elderly in maintaining their health. High quality of life will be obtained from the elderly who have good family support. Individuals learn to maintain healthy behavior that has been practiced by their families. Good family support will be positively related to healthy behavior of individuals. Elderly people who live with families with a positive functioning style can affect healthy lifestyle and good selfmanagement behavior. Good healthy behavior will be taught and maintained among family members (Huidobro et al., 2012).

\section{The effect of residence on the healthy behavior of the elderly}

Living at home increases healthy behavior; as a result, the quality of life of the elderly can improve. Good family support can affect the healthy behavior of the elderly. The elderly who lives in the community or at home have good healthy behavior because there is family who has a great influence on the healthy behavior of the elderly. Parents or elderly who live with their spouse and children at home have the highest level of physical activity and healthy behavior. They are more successful in managing their stress. It occurs because parents who live with their families may feel younger than other parents and can be more active (Harooni et al. 2014). In addition, environmental sanitation and adequate house condition can be important priorities in supporting the health of the elderly population (Blay et al., 2015).

\section{The effect of residence on the family support}

Elderly people who live at home had good family support. The elderly who live at home have a good coping mechanism because they can tell their families when having a problem. In addition, the elderly enjoy better social relation as they stay closer to the family members and neighbors around their homes. Family relationship provides resource that can help someone in overcoming stress, engaging in healthier behavior, and increasing self-esteem, which leads to higher well-being (Kumar et al., 2016). Each increase of 1 unit of residence 
at home with the family will increase family support by 22.93 units compared to the elderly who live in nursing home (Suwarni et al., 2018).

Based on the observation of this study, the elderly who lived in nursing home had different backgrounds and have weak family support. The elderly who lived in nursing home were usually caused by economic problem and conflict within the family. This is in line with a study conducted by Pouladi et al. (2013), that the elderly who live in nursing home usually have financial problem. In addition, this problem is one of the limiting factors in elderly care. Inadequate income, limited physical environment, and lack of time to take care of the elderly are used as reasons for sending the elderly to nursing homes (Hafshjani and Abedi, 2016).

\section{The effect of residence on the peer support}

Elderly who stay at home and actively participate in social interaction and social activity can help to stimulate their cognitive function, thus slowing the occurrence of dementia or senility. Good social engagement (maintaining, fostering various social relationships, and participating actively in social activities) can reduce cognitive decline in the elderly (Cahyaningtyas et al., 2019).

Peer support had a positive effect on the live of the elderly. This is in line with a study conducted by Suwarni et al. (2018) that peer support keeps the elderly motivated to continue living their lives. Friendship that exists between the elderly can have a positive impact on the social interaction of the elderly. In addition, peer support affects the health of the elderly (Suwarni et al., 2018).

The elderly who interact and share similar experiences with peers are the most important and meaningful aspects of their lives. Peer support shows positive result in increasing self-confidence, well-being and healthy behavior of the elderly (Chakkalackal, 2014).

\section{AUTHOR CONTRIBUTION}

Malinda Capri Nurul Satya was the main researcher who conducted this study. She collected data of the study, formulated the articles of the study, and processed the data. RB. Soemanto played a role in the formulation of background and discussion of the study. Bhisma Murti played a role in the formulation of the theoretical framework and analyzing data of the study.

\section{FUNDING AND SPONSORSHIP}

This study used personal funds from the main researcher.

\section{CONFLICT OF INTEREST}

There was no conflict of interest.

\section{ACKNOWLEDGEMENT}

We give the best gratitude to the Head of UPT Social Service of Tresna Werdha in Jember and the Head of Wuluhan Jember Community Health Center for allowing us to conduct this study. We also give the gratitude to all the elderly who have been willing and cooperative to become the respondents of the study.

\section{REFERENCE}

Andesty D, Syahrul F (2018). Hubungan interaksi sosial dengan kualitas hidup lansia di Unit Pelayanan Terpadu (UPTD) Griya Werdha Kota Surabaya Tahun 2017. The Indonesian Journal of Public Health, 13(2):171-182. doi: 10.204703.

Azwan, Herlina, Karim D (2015). Hubungan dukungan sosial teman sebaya dengan kualitas hidup lansia di panti sosial tresna werdha, Jurnal online 
Mahasiswa Program Studi Ilmu Keperawatan Universitas Riau (JOM PSIK UNRI), 2(2). Retrieved from: https://jom.unri.ac.id/index.php/JOMPSI $\mathrm{K} /$ article/view/8258.

Bahramnezhad F, Chalik R, Bastani F, Navab E (2017) The social network among the elderly and its relationship with quality of life, Electronic Physician, 9(5): 4306-4311. doi: 10.19082/4306.

Bilgili N, Sarpaci F (2014). Quality of life in older adults in Turkey, Arch Gerontol Geriatr, 59(2):415-421. doi:10.1016 j.archger/ 2014.07.005.

Blay SL, Schulz AJ, Mentz G (2015). The relationship of built environment to health related behaviors and health outcomes in elderly community residents in a middle income Country. $\mathrm{J}$ Public Health Res. 4(2):548. doi: 10.4081/jphr.2015.548.

BPS (2018). Statistik Penduduk lanjut usia 2018. Jakarta: Badan Pusat Statistik. Retrieved from: https://swebcache.googleusercontent.com/search?q=ca che:hZ3Q3xqUSqgJ:https://www.bps .go.id/publication/2018/12/21/eadba b6507c06294b74adf71/statistik_pend uduk_lanjut_usia_2018.html+\&cd=1 $\& \mathrm{hl}=\mathrm{id} \& \mathrm{ct}=\mathrm{clnk} \& \mathrm{gl}=\mathrm{id} \& \mathrm{client}=$ firefox -b-d.

Bryla M, Burzynska M, Maiecka BIM (2013). Self -rated quality of life of city-dwelling elderly people benefitting from social help: Results of a cross-sectional study. Health Qual Life Outcomes, 11(1):1-11. doi: 10.1186/1477-7525-11-181.

Cahyaningtyas NA, Sudiyanto A, Soemanto RB (2019). Socioeconomic determinants of healthy ageing and the contextual effect of peer group: A multilevel evidence from Blora, Central Java, J Epidemiol Public Healt, 4(1):
30-36. doi: https://doi.org/10.26911/jepublichealth.2019.04.01.04.

Chakkalackal L (2014). The value of peer support on cognitive improvement amongest older people living with dementia, Social Services Research Group, 31(2): 127-141. Retrieved from http://ssrg.org.uk/wpcontent/upload s/2015/o9/Chakkalackal_v2

Ferreira LK, Meireles JFF, Ferreira MEC (2018). Evaluation of lifestyle and quality of life in the elderly: A literature review, Rev Bras Geriatr Gerontol, 21(5):616627. doi:10.1590/198122562018021.180028.

Granbom M, Iwarsson S, Kylberg M, Pettersson C, Slaug B (2016). A public health perspective to environmental barriers and accessibility problems for senior citizens living in ordinary housing, BMC Public Health, 16(772):1-11. doi:s10.1186/s12889-0163369-2.

Hafshjani FC, Abedi HA (2016). A study of families experiences of putting their elders in nursing homes, Int. J. Med. Health Sci Res, 5(11):209-214. Retrieved from https://www.ijmrhs.com/medical_research/study_of_families _experiences_of_putting_their_elder s_in_nursing_homes.

Harooni J, Hassanzadeh A, Mostafavi F (2014). Influencing factors on health promoting behavior among the elderly living in the community, Journal of Education and Health Promotion, 3(40):132.doi: 10.4103/22779531.131 921

Hudoibro DG, Mendenhall T (2015). Family oriented care. Opportuinities for health promotion and disease prevention, J Fam Med Dis Prev. ISSN:24695793. Retrieved from: https://clinmedjournals.org/articles/jfmdp/jour 
nal-of-family-medicine-and-diseaseprevention-jfmdp-1-009.

Huidobro DG, Puschel K, Soto G (2012). Family functioning style and health : opportunities for health prevention in primary care, Br J Gen Pract, 62 (596): 198-203. doi: 10.3399/bjgp12X630098.

Kemenkes (2014). Infodatin situasi dan analisis lanjut usia (lansia). Jakarta: Kementerian Kesehatan Republik Indonesia. Retrieved from http://www.depkes.go.id/resources/download/pu sdatin/infodatin/infodatin-lansia.

Kemenkes (2016). Infodatin Situsi Lanjut Usia (Lansia) di Indonesia. Jakarta: Direktorat Bina Kesehatan Komunitas. Retrieved from: https://pusdatin.kemkes.go.id/article/view/160923 oooo2/infodatin-situasi-lanjut-usialansia-di-indonesia.html.

Kosim N, Nanik I, Siti K (2015). Faktor yang mempengaruhi kualitas hidup peduduk di Desa Sentul Kecamatan Sumber Suko Kabupaten Lumajang. Artikel Ilmiah Mahasiswa, Jember: Universitas Jember. Retrieved from: http://repository.unej.ac.id/bitstream /handle/123456789/64385/Nanang\% 20Kosim.

Kumar BAP, Eshwar SU, Arun D, Shravan S (2016). Quality of life of elderly people in institutional and non-institutional setting: a cross-sectional comparative study, Natl J Community Med, 7(7): 546-550. eISSN 2229 6816. Retrieved from:https://www.bibliomed.or/?mno $=241172$.

Layte R, Sexton E, Savva G (2013). Quality of life in older age: Evidence from an Irisch cohort study, J Am Geriatr Soc, 61(S2):S299-2305.doi:10.1111/jgs.12198.

Panday R, Kiran M, Srivastava P, Kumar S (2015). A study on quality of life between elderly people living in old age home and within family setup, Open J Psychiatry Allied Sci, 6(2):127. doi:10.5958/2394-2061.2015.00010.5 Pernambuco CS, Rodrigues BM, Cleria J, Bezerra P (2012). Quality of life, elderly and physical activity, Health Journal, 4(2):88-93. doi:10.4236/sshealth. 2012.42014.

Pouladi SH, Anoosheh M, Kazemnejed A, Zareiyan A (2013). Factors limiting families in elderly care: A thematic analysis, Qual Health Res, 2(2):14657. ISSN: 2645-6109. Retrieved from: http://jqr.kmu.ac.ir/browse.php?a_id $=175 \&$ sid $=1 \&$ slc $\_l a n g=e n$.

Prasetyaningsih R, Indarto D, Akhyar M (2016). Association of determinant factors on bio-psychosocial with quality of life in elderly, $\mathrm{J}$ Epidemiol Public Healt, 1(2):108-117. doi: 10.26911.

Sheridazeh Y, Sarkhoshi R, Babazadeh T, Moradi F, Shariat F, Mirzaian $\mathrm{K}$ (2016). The quality of life and its related factors in the elderly covered by health care centers in Khoy City. Journal Anal Res Clin Med. 4(3):139145.

Suwarni S, Soemanto RB, Sudiyanto A (2018). Effect of dementia, family support, peer support, type of residence, and marital status on quality of life of the elderly in Surakarta, Central Java, J Epidemiol Public Health, 3(1): 83-94. doi: 10.26911.

The World Bank (2018). Total population ages 65 and above. Retrieved from: https://data.worldbank.org/indicator /SP.POP.65UP.TO?end=2018\&start= 2016.

Uddin MA, Bhuiyan AJ (2019). Development of the family support scale (FSS) for elderly people, MOJ Gerontology 
and Geriatrics, 4(1):17-20. doi: 10.15406/mojgg.2019.04.00170.

Waterworth P, Pescud M, Braham R, Dimmock J, Rosenberg M (2015). Factors influencing the health behaviour of indigenous Australians: Perspectives from support people, PLoS ONE, 10(11):1-17.doi: 10.1371/journal pone 0142323.

Wulandari ASF (2011). Kejadian dan tingkat depresi pada lanjut usia: Studi perbandingan di Panti Wreda dan komunitas. Karya Tulis Ilmiah. Fakultas Kedokteran Universitas
Diponegoro Semarang. Retrieved from: http://eprints.undip.ac.id.

Yuliati A, Boroya N, Ririanty M (2014). The different of quality of life among the elderly who living at community and social services, e-Journal:Pustaka Kesehatan, 2(1):87-94. Retrieved from: https://jurnal.unej.ac.id/index.php/JPK/article/view/601. 